\title{
UPAYA MENINGKATKAN HASIL BELAJAR PKn PADA MATERI POKOK MENJAGA KEUTUHAN NKRI MELALUI METODE BERMAIN PERAN DENGAN MODEL PEMBELAJARAN COOPERATIVE LEARNING KELAS VI SEMESTER GENAP SD NEGERI 153071 SIBABANGUN 1 KABUPATEN TAPANULI TENGAH TAHUN PELAJARAN 2017 / 2018
}

\author{
Lailam Fajar \\ Guru SD Negeri 153071 Sibabangun 1 Kabupaten Tapanuli Tengah
}

\begin{abstract}
Abstrak
Melihat rendahnya keaktifan dan hasil belajar siswa pada mata pelajaran PKn difokuskan pada, 1). apakah penerapan metode bermain peran dengan model pembelajaran cooperative learning siswa Kelas VI SD Negeri 153071 Sibabangun 1 dapat meningkatkan keaktifan belajar PKn tentang Negara Kesatuan Republik Indonesia di Kelas VI SD Negeri 153071 Sibabangun 1 ? 2). Bagaimanakah penerapan metode pembelajaran bermain peran untuk meningkatkan hasil belajar PKn tentang Negara Kesatuan Republik Indonesia di Kelas VI SD Negeri 153071 Sibabangun 1 ?.1).Tujuan penelitian tindakan kelas ini adalah untuk Mencari informasi keaktifan siswa dalam pembelajaran PKn tentang Negara Kesatuan Republik Indonesia. 2.) mengetahui ada tidaknya peningkatan hasil belajar siswa terhadap pengambilan keputusan bersama siswa kelas VI SD Negeri 153071 Sibabangun 1.Prosedur penelitian ini meliputi 2 siklus dimana setiap siklus terdiri atas perencanaan, pelaksanaan, pengamatan, dan refleksi. Penelitian tindakan kelas ini dilaksanakan di SD Negeri 153071 Sibabangun 1, dengan obyek penelitian siswa kelas VI yang berjumlah 23 orang siswa yang terdiri atas 12 siswa perempuan dan 11 siswa laki-laki. Hasil penelitian menunjukkan bahwa pembelajaran PKn dengan menggunakan pembelajaran model pembelajaran cooperative learning melalui penerapan metode bermain peran dapat meningkatkan keaktifan belajar siswa dengan prosentase tiap siklus, sebelum perbaikan pembelajaran ada 12 siswa atau 52\% dari 23 siswa. Pada Perbaikan Pembelajaran Siklus I meningkat, siswa yang nilainya 75 keatas menjadi 16 atau 69\% dari 23 siswa dan pada perbaikan Siklus II menjadi 22 siswa atau $96 \%$.
\end{abstract}

Kata Kunci: Meningkatkan Hasil Belajar, Metode Bermain Peran, Model Cooperative Learning

\section{Pendahuluan}

Pelajaran Pendidikan

Kewarganegaraan ( PKn ) diberikan sejak di bangku SD sampai SLTA. Dengan PKn seseorang akan memiliki kemampuan untuk mengenal dan memahami karakter dan budaya bangsa serta menjadikan warga negara yang siap bersaing di dunia internasional tanpa meninggalkan jati diri bangsa. Melalui PKn setiap warga negara dapat mawas diri dengan perkembangan teknologi informasi dan komunikasi dewasa ini yang memberi 
dampak positif dan negatif. PKn juga bermanfaat untuk membekali peserta didik agar memiliki kemampuan untuk mengelola dan memanfaatkan informasi untuk bertahan hidup pada keadaan yang selalu berubah, tidak pasti dan kompetitif.

Pada kenyataannya, PKn dianggap ilmu yang sukar dan sulit dipahami. PKn adalah pelajaran formal yang berupa sejarah masa lampau, perkembangan sosial budaya, perkembangan teknologi, tata cara hidup bersosial, serta peraturan kenegaraan. Begitu luasnya materi PKn menyebabkan anak sulit untuk diajak berfikir kritis dan kreatif dalam menyikapi masalah yang berbeda. Sementara anak usia sekolah dasar tahap berfikir mereka masih belum formal, karena mereka baru berada pada tahap Operasional Konkret ( Peaget : 1920 ). Apa yang dianggap logis, jelas dan dapat dipelajari bagi orang dewasa, kadang - kadang merupakan hal yang tidak masuk akal dan membingungkan bagi siswa. Akibatnya banyak siswa yang tidak memahami konsep PKn.

Berdasarkan temuan penulis, sebagian besar siswa kurang aktif dan berfikir kritis dalam materi Negara Kesatuan Republik Indonesia ( NKRI ). Apabila anak menghadapi masalah kontekstual baru yang berbeda dengan yang dicontohkan, anak belum mampu berfikir kritis dan menemukan solusi dengan benar sehingga banyak anak yang menjawab salah, dan dengan alasan soalnya sulit. Karena itu wajar setiap kali diadakan tes, nilai pelajaran PKn selalu rendah dengan rata rata kurang dari KKM.
Seperti yang dialami penulis sendiri, setiap ulangan PKn nilai rata - rata anak di bawah 75. Termasuk pada materi Negara Kesatuan Republik Indonesia ( NKRI ). Nilai rata - rata formatif hanya 68. Dari 23 siswa hanya 12 siswa $52 \%$ yang memperoleh nilai 75 ke atas. Sedangkan 10 siswa yang lain $43 \%$ mendapat nilai dibawah 75 .

PKn merupakan mata pelajaran di sekolah yang perlu menyesuaikan diri sejalan dengan kebutuhan dan tuntutan masyarakat yang sedang berubah. Hal ini merupakan fungsi PKn sebagai pembangun karakter bangsa (nasional character building ) yang sejak proklamasi kemerdekaan RI telah mendapat prioritas, yang perlu direvitalisasi agar sesuai dengan arah dan pesan konstitusi Negara RI. Untuk itu pembentukan karakter anak yang kuat perlu penguasaan Pembelajaran Kewarganegaraan sejak dini.

Mata pelajaran PKn perlu diberikan kepada semua peserta didik mulai dari Sekolah Dasar karena PKn memiliki tugas pokok sebagai berikut :

1. Mengembangkan Kecerdasan Warga Negara ( civic intelligence ).

2. Membina tanggungjawab warga Negara ( civic intelligence ).

3. Mendorong partisipasi warga Negara ( civic intelligence).

Kecerdasan warga Negara yang dikembangkan untuk membentuk warga Negara yang baik bukan hanya dalam dimensi rasional melainkan juga dimensi spiritual, emosional, dan social sehingga PKn memiliki ciri multidimensional. 
Kompetensi tersebut diperlukan agar peserta didik dapat memiliki kemampuan untuk mengolah dan memanfaatkan informasi serta peka terhadap keadaan yang selalu berubah / tidak pasti.

Menurut hasil penelitian Cogan ( 1998 ), ada delapan karakter yang dapat dibentuk melalui belajar PKn yaitu sebagai berikut :

1. Kemampuan mengenal dan mendekati masalah sebagai warga masyarakat di sekitar.

2. Kemampuan bekerjasama dengan orang lain dan memikul tanggung jawab atas peran atau kewajibannya dalam masyarakat.

3. Kemampuan untuk memahami, menerima, dan menghormati perbedaan - perbedaan pendapat.

4. Kemampuan berfikir kritis dan sistematis.

5. Kemampuan menyelesaikan konflik dengan cara damai tanpa kekerasan.

6. Memiliki kemampuan untuk bergaya hidup sederhana.

7. Memiliki kepekaan terhadap lingkungan dan mempertahankan hak - haknya dalam masyarakat.

8. Memiliki kemauan dan kemampuan untuk berpartisipasi dalam kehidupan bermasyarakat.

Dengan demikian fungsi pembelajaran PKn tidak hanya sekadar memberi pengetahuan tentang pendidikan kewarganegaraan saja, tetapi juga dimaksudkan untuk mengembangkan sikap - sikap tertentu mengenai hal - hal yang timbul disekitar dalam kehidupan sehari hari.
Hasil belajar merupakan perubahan perilaku yang diperoleh pembelajar setelah mengalami aktivitas belajar ( Anni, 2004 : 4 )

Hasil belajar adalah perubahan perilaku yang relative menetap dalam diri seseorang sebagai akibat dari interaksi seseorang dengan lingkungannya ( Hamzah : 2007 : $213)$.

Berdasarkan pengertian hasil belajar di atas peneliti menyimpulkan bahwa aspek - aspek perubahan perilaku tersebut tergantung pada apa yang dipelajari oleh pembelajar. Oleh karena itu apabila pembelajar mempelajari tentang konsep, maka perubahan perilaku yang diperolah berupa penguasaan konsep. Dalam pembelajaran PKn pada materi Negara Kesatuan Republik Indonesia untuk mencapai hasil belajar yang memuaskan diperlukan aktivitas siswa yaitu dengan melakukan aktivitas langsung dalam menjaga keutuhan Negara Kesatuan Republik Indonesia . Melalui aktivitas tersebut pembelajar akan lebih mengena pada siswa. Selain itu siswa juga perlu berinteraksi dengan siswa yang lain untuk membuat simpulan dengan benar.

Menurut Joyce dan Weil 1971 model mengajar adalah kerangka konseptual yang melukiskan prosedur yang sistematis dalam mengorganisasikan pengalaman belajar untuk mencapai tujuan belajar tertentu, dan berfungsi sebagai pedoman bagi para perancang pembelajaran dan para pengajar dalam merencanakan dan melaksanakan aktivitas belajar mengajar. 
Model mengajar merupakan suatu rencana atau pola yang dapat digunakan untuk membentuk kurikulum, merancang bahan - bahan pengajaran, dan bimbingan pengajaran di kelas atau yang lain.

Menghadapi kenyataan tersebut di atas, penulis tertarik untuk mendalami dan melakukan tindakan - tindakan perbaikan pembelajaran PKn, khususnya materi Negara Kesatuan Republik Indonesia ( NKRI ) melalui penelitian tindakan kelas. Perbaikan yang penulis lakukan mengenai penerapan metode bermain peran pada materi pengambilan keputusan bersama. Harapan penulis adalah terjadinya pembelajaran aktif, kreatif dan menyenangkan serta lebih bermakna dan adanya keberanian peserta didik yang tuntas untuk menyelesaikan masalah kontektual dengan benar serta untuk lebih menguasai pelajaran.

Menurut Sumantri ( 2001 ) bermain peran merupakan model mengajar yang berakar pada dimensi personal dan sosial dari pendidikan. Model ini mencoba membantu indivisu untuk menemukan makna pribadi dalan dunia sosial dan memecahkan dilema - dilema dengan bantuan kelompok sosial. Dalam hal ini memungkinkan individu untuk bekerjasama untuk menganalisis situasi sosial terutama permasalahan interpersonal dalam mengembangkan cara - cara yang demokratis untuk menghadapi situasi tersebut.

Hipotesis yang penulis lakukan adalah dalam bentuk laporan hasil yaitu berjudul "Meningkatkan hasil belajar Pengambilan keputusan bersama melalui metode bermain peran dengan model pembelajaran cooperative learning siswa Kelas VI SD Negeri 153071 Sibabangun 1 Kabupaten Tapanuli Tengah.

\section{Metode Penelitian}

Tempat pelaksanaan perbaikan pembelajaran di SD Negeri 153071 Sibabangun 1 , Kecamatan Sibabangun, Kabupaten Tapanuli Tengah. Subjek penelitian adalah siswa Kelas VI semester genap, mata pelajaran PKn untuk materi Negara Kesatuan Republik Indonesia. Pelaksanaan pembelajaran diawali dengan melakukan pembelajaran awal. Pelaksanaannya dilakukan tiga kali yaitu pembelajaran awal (pra siklus), siklus I, dan siklus II. Masing masing terdiri dari perencanaan, pelaksanaan, pengamatan, dan refleksi.

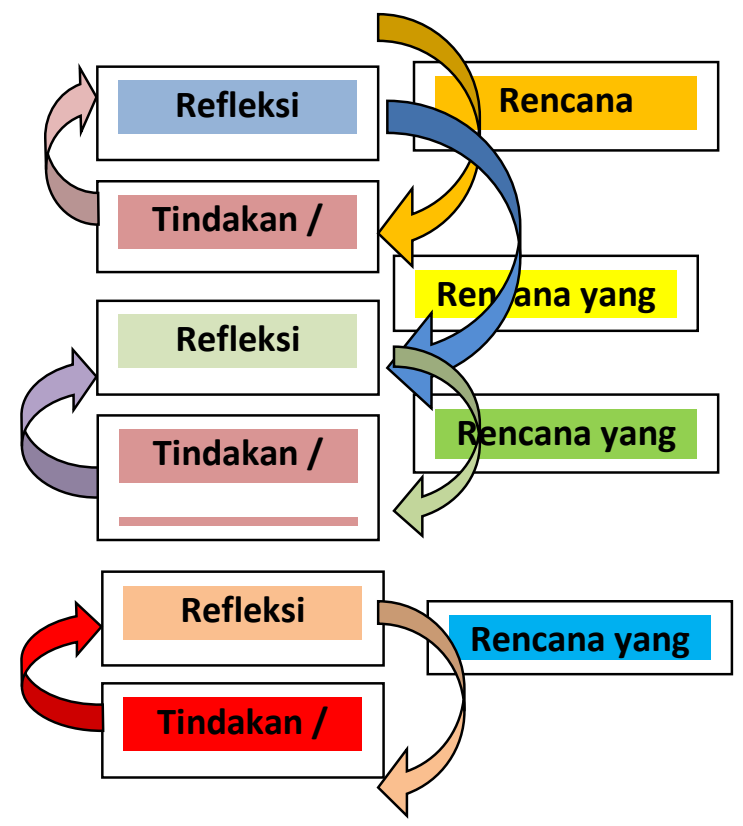

\section{Pembahasan dan Hasil}

Hasil penelitian yang dilakukan pada siswa Kelas VI SD Negeri 153071 Sibabangun 1, Kecamatan Sibabangun, 
Kabupaten Tapanuli Tengah terkait hasil belajar PKn tentang Negara Kesatuan Republik Indonesia melalui metode bermain peran dengan model pembelajaran cooperative learning, yang dilaksanakan dalam perbaikan pembelajaran pada siklus I dan siklus II.

Tabel 1

Analisis Hasil Tes Formatif Pra Siklus Mata Pelajaran PKn

\begin{tabular}{|c|c|c|}
\hline No & Rentang & Frekuensi \\
\hline 1 & $41-50$ & 2 \\
2 & $51-60$ & 5 \\
3 & $61-70$ & 4 \\
4 & $71-80$ & 9 \\
5 & $81-90$ & 3 \\
6 & $91-100$ & \\
\hline & Jumlah & $\mathbf{2 3}$ \\
\hline
\end{tabular}

Berdasarkan tabel 1 diatas, penguasaan materi pembelajarn pra siklus bahwa dari jumlah 23 siswa yang mendapat nilai 41 sampai 50 sebanyak 2 siswa, yang mendapat nilai 51 sampai 60 sebanyak 5 siswa, nilai 61 sampai 70 sebanyak 4 siswa, nilai 71 sampai 80 sebamyak 9 siswa, nilai 81 sampai 90 sebanyak 3 siswa dan tidak ada yang mendapat nilai diatas 91 .

Dengan demikian tindakan perbaikan pembelajaran PKn dengan materi pokok Negara Kesatuan Republik Indonesia Kelas VI semester II di SD Negeri 153071 Sibabangun 1, Kecamatan Sibabangun Kabupaten Tapanuli Tengah melalui model pembelajaran cooperative learning melalui metode bermain peran dengan mengefektifkan alat peraga kebudayaan dan globe dipandang sudah cukup. Hal ini terbukti adanya peningkatan hasil belajar atau hasil evaluasi nilai rata - rata sudah diatas KKM yaitu 90 dan tingkat ketuntasan $96 \%$.

\section{Kesimpulan}

Setelah peneliti melaksanakan perbaikan pembelajaran melalui pembelajaran siklus I dan siklus II dengan materi Negara Kesatuan Republik Indonesia di kelas VI semester genap tahun pelajaran 2017/2018 di SD Negeri 153071 Sibabangun 1, Kecamatan Sibabangun, Kabupaten Tapanuli Tengah, maka penulis dapat mengambil kesimpulan bahwa upaya meningkatkan prestasi belajar siswa dengan metode bermain peran melalui pendekatan model cooperative learning dengan mengefektifkan alat peraga kebudayaan dan globe telah mampu meningkatkan hasil belajar siswa.

Peningkatan ini terjadi pada siklus I maupun siklus II dengan bukti adanya peningkatan pada antara lain :

1. Menggunakan media pembelajaran kebudayaan dan globe dapat meningkatkan pemahaman siswa terhadap materi Negara Kesatuan Republik Indonesia.

2. Model pembelajaran cooperative learning melalui penerapan metode bermain peran untuk dengan mengefektifkan alat peraga dapat meningkatkan hasil belajar siswa.

3. Prosentase ketuntasan belajar siswa mengalami peningkatan yang signifikan setelah dilakukan perbaikan pembelajaran pada 
evaluasi sebelum perbaikan pembelajaran ada 12 siswa atau 52\% dari 23 siswa. Pada perbaikan pembelajaran siklus I meningkat, siswa yang nilainya 75 keatas menjadi 16 atau 69\% dari jumlah 23 siswa dan pada perbaikan siklus II menjadi 22 siswa atau $96 \%$.

\section{Saran}

Berdasarkan pengalaman peneliti selama melaksanakan Penelitian Tindakan Kelas untuk meningkatkan prestasi belajar siswa SD Negeri 153071 Sibabangun 1, Kecamatan Sibabangun Kabupaten Tapanuli Tengah peneliti kemukakan saran sebagai berikut :

1. Guru sebaiknya mengusahakan media pembelajaran benda - benda konkret yang berada disekitar siswa dapat menghilangkan verbalisme dan menyenangkan.

2. Guru harus memberi motivasi dan bimbimngan pada siswa yang mengalami kesulitan.

3. Guru hendaknya menciptakan suasana belajar yang menyenangkan.

4. Pada era kompetisi siswa perlu dilatih untuk berani mengemukakan pendapat oleh karena itu latihan membimbing kawan - kawannya dalam melakukan bermain peran merupakan ajang latihan yang cukup kreatif.

5. Siswa perlu dilatih untuk bergaul dan bekerjasama yang harmonis dalam kelompoknya dengan kegiatan yang positif. Oleh karena itu bekerja dalam kelompok untuk menyelesaikan tugas tertentu merupakan cara yang efektif untuk melatih sifat sosial pada siswa.

6. Laporan ini dapat dijadikan bahan kajian untuk meningkatkan pengetahuannya melalui forum MGMP dan lain - lain.

\section{Daftar Pustaka}

Aswani, Zaenul,2004, Tes dan Asesmen di SD, Jakarta, Universitas Terbuka.

Andayani, dkk. 2010, Pemantapan Kemampuan Profesional. Jakarta, Universitas Terbuka.

Denny, Setyawan, 2005, Komputer dan Media Pembelajaran, Jakarta, Universitas Terbuka.

Gatot, Muhsetyo, Drs. M.Sc, dkk, 2007, Pembelajaran $P K n$, Jakarta, Universitas Terbuka.

Mulyani Sumantri, Nana Syaodih. 2007. Perkembangan Peserta Didik. Jakarta, Universitas Terbuka.

Pranaja S dkk, Buku Fokus PKn untuk SD Kelas VI, Jakarta, Sindutama.

Sriwilujeng,Dyah, Buku PKn untuk SD Kelas VI, Jakarta, Esis.

Samsudin, Abin, 2004, Profesi Keguruan 2, Jakarta, Universitas Terbuka.

Suciati, Drs. Dkk, 2004, Belajar dan Pembelajaran 2, Jakarta, universitas Terbuka.

Wardani, I.G.A.K, 2008, Penelitian Tindakan Kelas, Jakarta, Universitas Terbuka. 
Wahyudi Duin, Supaiyati, Ishak, Abduhak, 2001, Pengantar Pendidikan, Jakarta, Universitas Terbuka. 